\title{
Safe operating space for humanity at a regional scale
}

\author{
John F. McLaughlin ${ }^{1}$
}

ABSTRACT. The planetary boundaries framework defined safe limits to human impacts on essential Earth-system processes. Subsequent assessments concluded that impacts exceed most delineated boundaries. Societal responses to these results have been insufficient to restore safety. One factor impeding effective action is differences in scale between planetary boundaries and national, regional, or local scales where many impacts and solutions originate. I have contributed toward a resolution by developing a regional scale framework and an approach to translate boundaries across spatial scales. I developed the framework for a county and river basin in the Pacific Northwest. The framework includes six state variables related to planetary scale analogues. Boundary translation can be achieved by aggregating hydrologic processes across scales. Because of greater process certainty and lower spatial heterogeneity at the regional scale, regional boundaries can be defined with more precision than global analogues. The region has exceeded five boundaries and is close to the remaining one. Effects of existing and proposed policies will be to exceed boundaries further. Likely consequences include irreversible degradation in river functions, severe water shortages, impaired water quality, human health impacts, and extinctions of iconic salmonids. In most cases, policy and enforcement mechanisms to restore conditions within regional boundaries are in place, but they have been ignored or misapplied. New initiatives with potential to restore safety are being pursued by indigenous peoples, who also are most directly affected by boundary transgression. By clearly delineating regional boundaries and identifying consequences of boundary transgression, this framework may complement indigenous efforts with policy imperatives for other stakeholders in the region.

Key Words: forest cover; in-stream flow; land development; nitrate; Pacific Northwest; phosphorus; regional boundaries; riparian forest; salmon; scale translation

\section{INTRODUCTION}

The planetary boundaries framework (Rockström et al. 2009a, $b$, Steffen et al. 2015) delineates limits for humanity in the Anthropocene epoch. The framework identifies 11 biophysical processes that determine environmental function at a planetary scale and that have been affected severely by human activities. For each process, it determines boundaries beyond which the Earth system could shift to a state incompatible with human civilization and persistence of many species (Barnosky et al. 2012, Hughes et al. 2013). The latest assessment concluded that the Earth system remains within boundaries of 3 processes, but that humanity has driven the Earth system beyond a safe operating space for 5 processes (Steffen et al. 2015). Sufficient data are lacking to determine the status of the 3 remaining processes.

These results should compel rapid and comprehensive responses in societies around the planet. To date, such responses have been inadequate, although there are several regional exceptions (Jones et al. 2010, Zheng et al. 2016). Many factors underlie the discrepancy between planetary boundary analysis and societal responses. First, international environmental treaties are difficult to enact, implement, and enforce (Feldman 1992, Foster 2014). Second, responses are impeded by differences between the global scale of planetary boundaries and the national, regional, and local scales where policy decisions are made (Nykvist et al. 2013, Cole et al. 2014, Dearing et al. 2014, Häyhä et al. 2016, Verburg et al. 2016). These policies and decisions would be informed by local or regional analogues to planetary boundaries.

Heterogeneity in resource distribution and human impacts further compel regional boundary identification. Regional state shifts may occur earliest where resource use is excessive, even though processes at the planetary scale may remain within global boundaries (Brook et al. 2013). Heterogeneity in biophysical circulation and transport processes can cause systemic impacts to cascade through the Earth system. For example, interactions between atmospheric circulation patterns and forest clearing in the Amazon basin can alter precipitation in distant continents (Badger and Dirmeyer 2016). Deforestation can alter circulation patterns themselves in ways that differ among regions (McGuffie et al. 1995). Regional boundaries also are needed for critical regions where impacts can cause global consequences even though global variables may remain within safe limits (Nykvist et al. 2013). Each of these forms of heterogeneity, (1) impact variation, (2) distance between uses and impacts, and (3) disproportionately important "hot spot" regions, imply a need for delineating regionspecific boundaries.

Establishing regional boundaries would contribute to the planetary boundary approach, because six global boundaries involve processes that aggregate from regional to planetary scales (Nykvist et al. 2013, Dao et al. 2015). For those processes, remaining within regional boundaries is a prerequisite for respecting planetary limits (Nykvist et al. 2013, Cole et al. 2014, Dearing et al. 2014, Häyhä et al. 2016).

Regional-scale boundaries need delineation because resource management and land use often do not consider limits or thresholds. Many policy analysis frameworks implicitly devalue safe operating space for future generations by applying economic discounting: ascribing exponentially declining values to future conditions. In Washington State (USA), many resource and landuse decisions are determined through comprehensive planning, which requires counties and cities to accommodate population 
growth within a 20 -year planning horizon without consideration of biophysical process boundaries (Washington State Legislature 1990). Planning laws in most other U.S. states contain similar provisions (Zovanyi 1998).

Regional boundaries need to be delineated even if policy mandates to minimize environmental impacts are in place. Environmental responses that warn of approaching thresholds may not be evident (Hastings and Wysham 2010, Boettiger and Hastings 2013) or provide sufficient lead time to mount effective policy and management responses (Biggs et al. 2009). These concerns become magnified when impacts beyond boundaries are irreversible (Scheffer et al. 2012, Pace et al. 2015). When the time required to change policy and practice exceeds the latency between environmental warnings and threshold transgression, proactive mechanisms to maintain safety margins are required (Lindenmayer et al. 2016). Boundary delineation supports these mechanisms.

In the years since the planetary boundaries framework was developed, several comprehensive analyses have been conducted at subglobal scales (Häyhä et al. 2016). Three studies identified national analogues for each planetary variable and determined relevant limits for the focal nations (Nykvist et al. 2013, Cole et al. 2014, Dao et al. 2015). For processes characterized by wellmixed stressors, such as climate change, ocean acidification, and stratospheric ozone depletion, these analyses applied linear downscaling from global limits to determine per capita shares. Then they aggregated per capita shares to national levels and compared observed national impacts with downscaled planetary boundaries. Two analyses (Nykvist et al. 2013, Dao et al. 2015) applied a similar downscaling method to derive national limits for other planetary boundaries. In contrast, Cole et al. (2014) recognized that processes in highly structured media are "intrinsically scale dependent" and should be analyzed at subglobal levels. They adjusted planetary boundaries to reflect regional conditions and data available for land use, freshwater use, nutrient cycles, and biodiversity loss. Cole et al. (2017) resolved their (2014) national framework into province-specific analyses for each of South Africa's nine provinces. They applied three methods: downscaling national values to the provinces, aggregating local data to the provincial level, and constructing provincial values by fitting ecological units into administrative borders. They found the first method inadequately addressed regional heterogeneity for the same reasons that limit accuracy in downscaling from planetary to national scales. The two "bottomup" methods addressed heterogeneity more accurately but were challenging because of data gaps, inconsistencies, and discrepancies between ecological and political borders. Cole et al. (2017) also found that developing a consistent set of indicators facilitated comparisons among provinces and identification of province-specific priorities. Teah et al. (2016) analyzed a river basin in northwestern China by downscaling planetary boundaries to regionally relevant variables and comparing local perceptions derived from semistructured interviews of local residents. They delineated regional boundaries and current status for five processes: freshwater use; biogeochemical flows, i.e., nitrogen and phosphorus; land-system change; atmospheric aerosol loading; and chemical pollution. Dearing et al. (2014) applied a different approach for two rural regions in eastern and southwestern China. They analyzed time series data for soil erosion, air quality, and water quality to detect changes in environmental dynamics indicative of approaching state transitions. Their results have strong implications for social and environmental management in those regions, although connections to planetary boundaries are less clear. Finally, safe operating spaces have been developed for ecosystem components, including wetlands (Green et al. 2017) and fisheries Carpenter et al. (2017).

There is little methodological consistency among these studies, as noted by Häyhä et al. (2016). If the priority is to maintain local environmental functions within desirable bounds, consistency is unnecessary. Consistency and cross-scale translation are required, however, if regional and national boundary delineations are to support the planetary framework. Interregional consistency could be achieved using linear downscaling from planetary boundaries, but spatial heterogeneity and scale dependency of most processes render this approach inadequate (Cole et al. 2014, Häyhä et al. 2016). This problem also occurs when data at the national scale are downscaled to a regional scale (Cole et al. 2017). The heterogeneous and local nature of most drivers of environmental change (Cole et al. 2014) suggests that regionspecific boundaries are needed. Nevertheless, regional boundaries lead to conceptual challenges of reconciling interregional differences and translating up to national and global levels.

I address two linked goals: (1) developing a region-specific boundary framework and (2) providing a mechanism for translating regional boundaries to broader scales. The focal region is a county and its associated river basin in Washington State (USA). To simplify boundary delineation, the focal region consists of an independent basin that discharges directly into the sea. Future analyses should address scale translation within and among large basins.

\section{FOCAL REGION: WHATCOM COUNTY, WASHINGTON STATE (USA)}

Whatcom County spans $6480 \mathrm{~km}^{2}$ located in the northwest corner of Washington State and the coterminous United States. It is bounded on the north by the U.S.-Canada border, on the west by the Salish Sea, on the east by the Cascades mountain crest, and on the south by Skagit County. The eastern two-thirds of Whatcom County is within the Mount Baker-Snoqualmie National Forest and North Cascades National Park, managed by the federal government. Most of the human population of 216,300 (Washington State Office of Financial Management 2017) resides in the western third of the county. Much of this area lies within the Nooksack River basin, $2155 \mathrm{~km}^{2}$ in extent, with most of the remainder in small independent watersheds.

The county is within the traditional territories of the Lummi Indian Nation and the Nooksack Tribe, who retain reservations and trust lands in the western third of the county. Euro-Americans began settling the region in the 1850 s, drawn by opportunities for logging, mining, and farming (Northwest Indian Fisheries Commission [NWIFC] 2016). During the following century, most of the forested land of the main-stem Nooksack subbasin was cleared and converted to agricultural uses (NWIFC 2016). Since 1950 , some agricultural land and remaining forest land have been converted to residential, commercial, and industrial uses. The trend of expanding land development is expected to continue because of both endogenous growth and the county's position 
between the Vancouver, British Columbia, metro area to the north and the Puget Sound (Seattle-Tacoma) metro area to the south.

Forty percent of the population lives in the county's largest city, Bellingham; $17 \%$ lives in six smaller cities and towns to the north and east; and the remaining $43 \%$ lives in unincorporated rural areas. Approximately half of the county population obtains domestic water from Lake Whatcom, which is augmented by diversion from the Middle Fork of the Nooksack River. The other half obtains water from the Nooksack River or groundwater wells. All Nooksack subbasins are closed to further water withdrawal year-round or during the summer dry season (Water Resources Program, Washington State Department of Ecology 2016). Environmental quality is valued highly in the region, which many consider a "second paycheck" (Public Financial Management Inc. 2015).

\section{TRANSLATING BOUNDARIES ACROSS SPATIAL SCALES}

Earth-system processes span a wide range of spatial scales. Boundaries determined for one scale can be translated to another scale using methods appropriate to the kind of process involved. Three of the 11 global processes, i.e., climate change, stratospheric ozone depletion, and ocean acidification, are driven by locally produced stressors that accumulate globally in well-mixed media. These processes occur at a global scale, with regional limits that can be determined by linear downscaling (Nykvist et al. 2013, Häyhä et al. 2016). Alternative downscaling approaches to national or regional allocations have been proposed using socioeconomic, efficiency, or equity criteria. These approaches include perpetuating current allocations in stressor production, shifting to equal per capita allocation, considering national or regional capacity for stressor adjustments, and accounting for historical responsibility in stressor production (Gignac and Matthews 2015). I will not consider boundaries for well-mixed stressors any further, although per capita driver emissions from the focal region are similar to U.S. national averages, which exceed national boundaries for all three variables (per capita values and national totals for the United States and 60 other nations are in Nykvist et al. [2013]). Two global processes, production of novel entities and atmospheric aerosol loading, have not been quantified at a global level (Steffen et al. 2015). Both processes are partially measured within the focal region, but in the absence of national or global boundaries and mechanisms to link them, I will not consider them. The remaining six global processes, i.e., land-system change, freshwater use, phosphorus and nitrogen flows, genetic biodiversity, and functional biodiversity, result from aggregation of locally produced drivers with heterogeneous distributions and impacts. Translating boundaries for these processes across scales is the key challenge in efforts to relate regional impacts to global processes and, conversely, to determine regional limits consistent with global boundaries. This challenge has remained elusive in part because analyses at different scales usually have applied different methods (Häyhä et al. 2016).

Cross-scale interactions have received extensive study (e.g., O'Neill et al. 1986, Daskalov et al. 2017, Getz et al. 2018, Palmquist et al. 2018). This literature can be summarized simplistically as follows: properties at coarse scales constrain phenomena at fine scales, and fine scale mechanisms aggregate to determine properties at coarse scales. These principles provide insight that can be applied to boundary translation across scales. In most regions, ecosystem states relevant to boundary processes are constrained by precipitation regimes. Precipitation quantity and timing strongly influence biogeochemical flows, freshwater availability, potential terrestrial vegetation types and land uses, and biodiversity composition and functions. Conversely, mechanisms determining these properties often involve hydrologic processes. Hydrologic processes also provide connectivity within and between subbasins that may confer local resilience to local perturbations. In basins with abundant anadromous fish, return of spawning adults also provides upstream connectivity. Strong spatial connectivity also may lead to catastrophic state change when stressors exceed critical levels (Scheffer et al. 2012, Hughes et al. 2013). These considerations suggest that effective boundary translation across scales could involve hydrologic processes (Perveen 2012), which are more amenable to cross-scale modeling than terrestrial phenomena (Giorgi and Avissar 1997). Accordingly, this regional boundary analysis includes hydrologic processes where relevant, in variable selection, boundary delineation, or impact identification.

\section{SELECTING REGIONAL BOUNDARIES}

To facilitate regional-global scale integration, I identified regional analogues for global control variables in Steffen et al. (2015). First, I resolved regional systems into causal chains linking human activities to resultant impacts. At each scale, Earth-system processes function in a web of interactions among anthropogenic and nonanthropogenic stressors, diverse system components, feedbacks, and affected entities. Effective societal interventions must act on stressors rather than impacts (Hughes et al. 2013). Intervention design, including selecting indicator variables and identifying policy options, is clarified by delineating causal pathways connecting drivers to impacts. I applied a driverpressure-state-impact-response (DPSIR) framework for these purposes, similar to other subglobal analyses (Nykvist et al. 2013, Dao et al. 2015, Teah et al. 2016). DPSIR frameworks outline causal chains linking anthropogenic stressors or drivers, system fluxes or pressures, system states affected by fluxes, impacts resulting from state changes, and societal responses to modify drivers or pressures. Boundaries identify states at the limit of safety (Dao et al. 2015). Accordingly, I selected variables that measure state position, rather than other DPSIR components (Fig. 1). The state criterion caused some discontinuity with the planetary boundary framework (Steffen et al. 2015), which included two drivers, one pressure, five states, and two impacts. (Indicator for the 11th planetary process was not identified.)

I restricted boundary selection to regionally heterogeneous processes in structured media: land-system change, freshwater use, phosphorus flows, nitrogen flows, genetic biodiversity loss, and functional biodiversity loss. I then excluded biodiversity losses as state indicators because biodiversity losses are impacts rather than states. Instead, I verified that selected indicators contained strong links to regional biodiversity.

I selected indicator variables and boundaries using ordered sets of criteria (Table 1). To be selected, candidate indicator variables and boundaries had to fulfill all criteria. If a candidate failed to fulfill any criterion, I repeated the criteria review process with alternative candidates until all criteria were met. Boundary criteria ensured relevance to planetary boundaries, regional 
Fig. 1. Causal chain diagram for regional boundaries, using a driver-pressure-state-impact-response (DPSIR) framework, similar to Nykvist et al. (2013). DPSIR categories are defined in the text. Regional boundaries are safe limits on state variables. Societal responses should modify drivers or pressures to maintain state variables within boundaries. Many impacts function as drivers to other impacts, not shown here. For example, hydrologic impacts also affect biodiversity composition and functions. Planetary analogs to regional boundaries are listed on the left for reference. TIA, total impervious surface area.

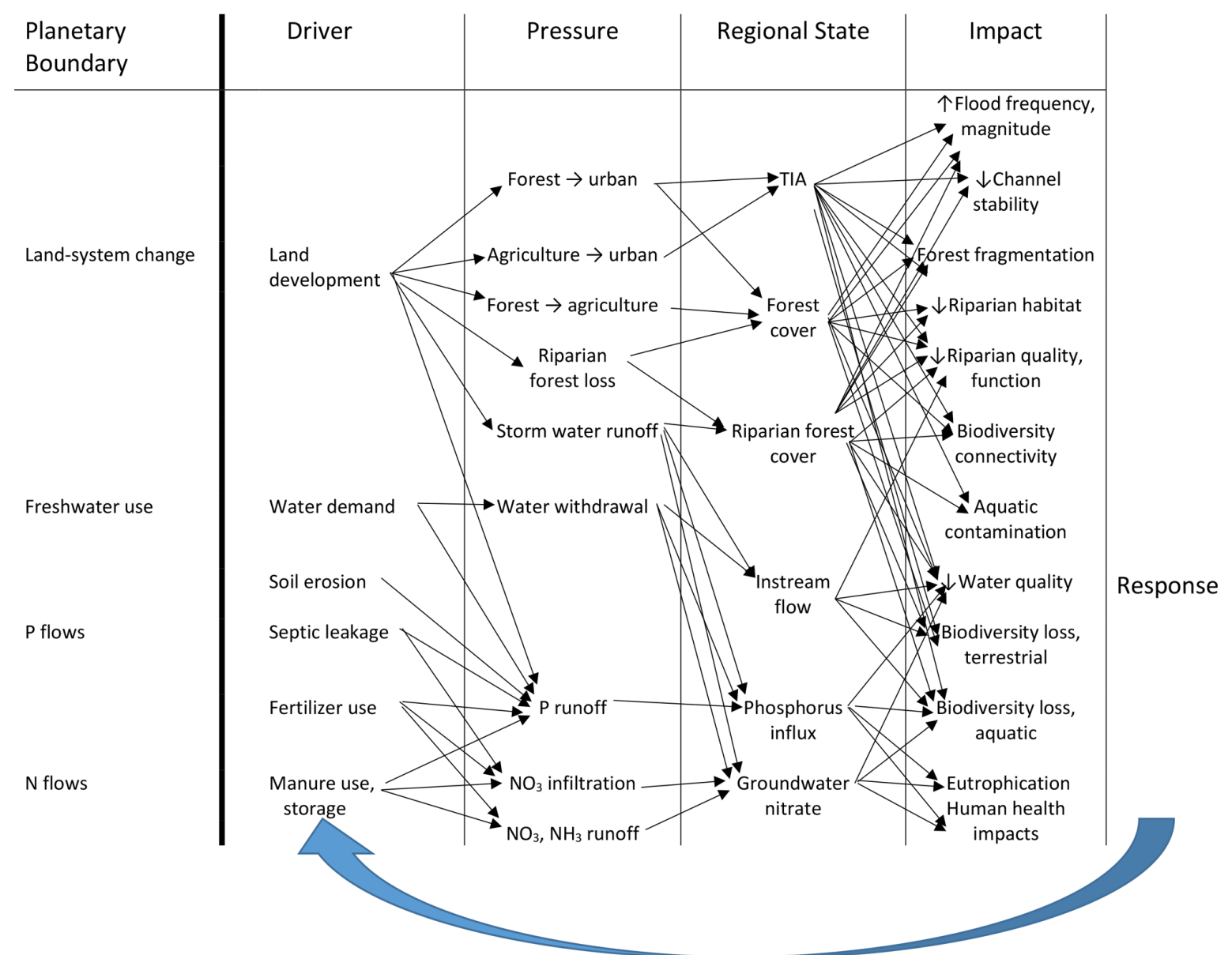

processes, threshold phenomena, the DPSIR framework, and scale translation. Indicator criteria ensured relevance to regional status, DPSIR causal chains, scale translation, threshold phenomena, and data availability. Data sources for boundary values included peer-reviewed literature and reports by or to state agencies. Data sources for current indicator values included federal agency river gauges, reports by or to state agencies, and county planning documents.

I resolved land-system change into three regional components: forest cover, riparian forest cover, and land conversion to impervious surfaces. Partitioning forest cover into upland and riparian zones is warranted because of divergent causal links to different impacts, particularly to distinct biodiversity elements and functions (Hjältén et al. 2016). I selected Nooksack River instream flow to represent freshwater use, because it constitutes the river state after withdrawals from surface and groundwater sources. I selected phosphorus influx and nitrate contamination in the two most important water bodies affected by those elements.
Each of these variables exerts direct or indirect effects on regional analogues of the genetic and functional biodiversity global variables (Fig. 1).

\section{QUANTIFYING REGIONAL BOUNDARIES}

\section{Land surface development}

Intensive land development affects many important biophysical processes, including carbon and nutrient cycles, air quality, solar absorption and reflection, stream hydrology, channel stability, aquifer recharge, soil development and erosion, contaminant runoff, and wildlife habitat extent and connectivity. Cumulative effects of land development manifest at a watershed scale, where impacts integrate to force river functions beyond their natural range of variability (Poff et al. 1997). In the Pacific Northwest and other regions with moist climates, rivers provide more sensitive indicators of destabilizing land-system change than terrestrial variables because river impacts become irreversible (Booth et al. 2002) at land conversion levels much lower than 
Table 1. Ordered selection criteria for regional boundaries and state indicator variables. Candidate boundary and indicator variables were compared with criteria in ascending order. Variables that did not meet a criterion were discarded, and evaluation proceeded with alternative variables.

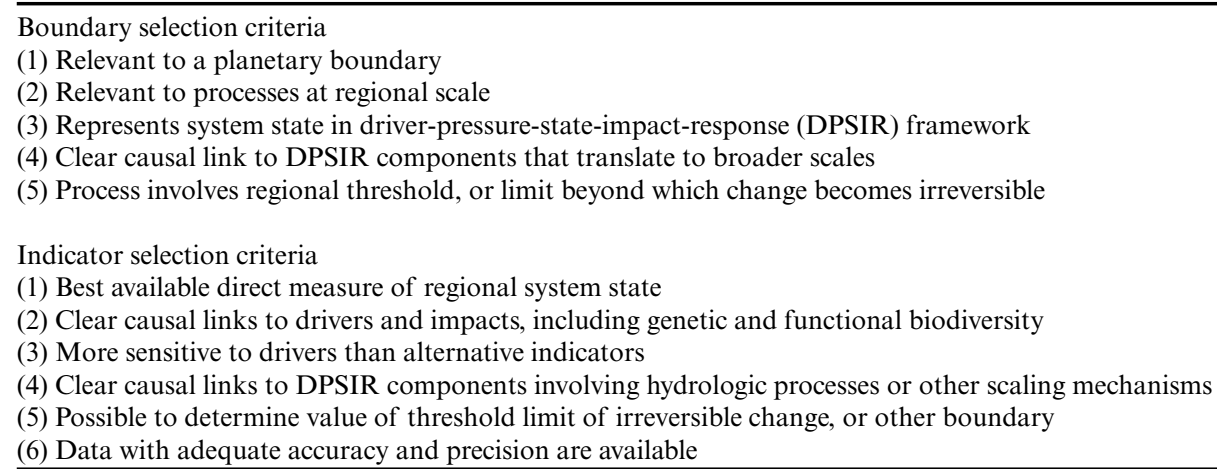

thresholds of terrestrial habitat fragmentation and other terrestrial functions (Swift and Hannon 2010). Consequently, the regional boundary for land development is determined by impacts to rivers. Land conversion destabilizes stream channels, increases hydrologic variability, reduces water quality, disrupts biodiversity functions, and causes species extinctions. In particular, land conversion impacts in the Pacific Northwest have been important drivers of declines and extirpations of wild Pacific salmon, which are iconic to the region (Lichatowich 2013). In addition to being among the region's most important genetic and functional biodiversity components (Cederholm et al. 2000, Helfield and Naiman 2006), Pacific salmon are essential to the sustenance and cultural identities of Coast Salish indigenous peoples (NWIFC 2012, 2016). Impacts to salmon are particularly important because indigenous peoples in the region have been disproportionately affected by boundary transgression. Although this analysis focuses on biophysical boundaries, considering impacts to salmon and their importance to indigenous peoples would facilitate extension of the regional framework in an ethical dimension (Raworth 2012, Häyhä et al. 2016).

Three stages characterize degradation of Pacific Northwest rivers from "salmon factories" (Lichatowich 2013) to urbanized causeways hostile to salmon and most other native riverine biota. First, forests are cleared to extract forest products or to clear land for agricultural, residential, commercial, or industrial uses. Forest removal accounts for roughly half of the impact to streams and salmon caused by intensive development (Pess et al. 2002). These impacts are reversible on decades- to century-long timescales if forest is restored to cleared land, but they become irreversible in subsequent stages.

In the second stage, cleared lands are converted to more intensive uses, and soils are covered with impervious surfaces. Increasing watershed development degrades riparian structure and function in diverse ways, causing unstable geomorphology, volatile hydrology, reduced aquifer recharge, decreased water quality, degraded riparian vegetation, and reduced diversity and abundance of aquatic biota (Booth and Jackson 1997, Moscrip and Montgomery 1997, Brabec et al. 2002, Allan 2004, Konrad and Booth 2005, Alberti et al. 2007, Schiff and Benoit 2007, Lohse et al. 2008, Ward et al. 2015). Third-stage development impacts occur when urban contaminants flush into rivers and streams.
Contaminant pulses, particularly during rainstorms following dry periods, kill coho salmon (Oncorhynchus kisutch) prematurely before they spawn (Feist et al. 2011, 2017).

Impervious surface area often serves as a surrogate for land development (Alberti et al. 2007). Riverine impacts increase continuously with increasing development (Booth et al. 2002), but they consistently become irreversible beyond $10 \%$ total impervious surface area (TIA; Booth and Jackson 1997, Booth et al. 2002). These impacts occur regardless of "best management practices," "low-impact development" measures, critical area buffers, or other mitigation measures (Booth et al. 2002). Development impacts cause large declines in aquatic invertebrates eaten by salmon (Booth and Jackson 1997, Booth et al. 2002, Brabec et al. 2002, Schiff and Benoit 2007, Lohse et al. 2008, Roni et al. 2008) and extirpations of sensitive species (Limburg and Schmidt 1990, Stranko et al. 2008, Jorgensen et al. 2009). Salmonids suffer declines or extirpations at similar levels of watershed development (Moscrip and Montgomery 1997, Pess et al. 2002, Lohse et al. 2008, Jorgensen et al. 2009).

The boundary for land development should be set at TIA of no more than $10 \%$ watershed area, because of severe geomorphic, hydrologic, and biotic impacts beyond this level. Beyond $10 \%$ TIA, risk of erosion escalates because of increased flood frequency, increased flood magnitude, and resulting channel instability. During the dry season, water quality becomes unacceptable because of low flows, high temperatures, low dissolved oxygen concentrations, and disproportionally high storm-water contaminant inputs. Development impacts during both wet and dry seasons elevate extirpation risk of aquatic biota. Land development beyond 10\% TIA also forecloses on options to mitigate climate change, because land development compounds hydrologic impacts of climate change (Cuo et al. 2009, Ward et al. 2015). In upper basins that provide essential Chinook salmon (Oncorhynchus tshawytscha) spawning habitat, the TIA limit should be 3\% (Water Resource Inventory Area [WRIA] 1 Salmon Recovery Board 2005b).

\section{Current status}

Currently, impervious surface development in two of the three upper Nooksack subbasins exceeds the 3\% limit, but all upper subbasins are below 10\% TIA (Table 2). Federal and state 
ownership of most upper subbasin land is likely to constrain impervious surface area in these subbasins. In the main-stem Nooksack, development exceeds $10 \%$ TIA (Table 2). Urban development is more extensive, exceeding $30 \%$ in some watersheds (Whatcom County Planning and Development Services 2015). Additional development planned or in progress will increase TIA further (Table 2).

Table 2. Total impervious surface area (TIA) in selected Whatcom County subbasins: current values and 20-year growth projections. Excerpted from table 4.3-3 in Whatcom County Planning and Development Services (2015).

\begin{tabular}{lcc}
\hline \hline Watershed/Subbasin & Existing TIA (\%) & Projected TIA (\%) \\
\hline North Fork Nooksack & 3.2 & 3.5 \\
Middle Fork & 1.9 & 1.9 \\
Nooksack & & \\
South Fork Nooksack & 3.5 & 3.6 \\
Main-stem Nooksack & 13.6 & 16.4 \\
Silver-Nooksack & 38.2 & 43.0 \\
Bellingham Bay & 43.6 & 47.7 \\
Squalicum & 27.0 & 31.4 \\
Lake Whatcom & 9.7 & 11.6 \\
\hline
\end{tabular}

\section{Forest cover}

Steffen et al. (2015) selected forest cover as a planetary boundary because of forest-atmosphere interactions that regulate climate. Forests also perform important functions at a regional level, including building and stabilizing soils, providing biodiversity habitat, facilitating aquifer recharge, moderating high stream flows in winter, and maintaining stream flows in summer (Cuo et al. 2009). Forest functions are expected to increase in importance with needs to mitigate hydrologic impacts of climate change (Battin et al. 2007).

The global forest cover boundary location is tentative and uncertain (Steffen et al. 2015). For the Nooksack basin, the regional boundary can be stated more precisely at $60 \%$ of basin area (WRIA 1 Salmon Recovery Board 2005a). At forest cover below $60 \%$, risks of floods causing redd scour and inadequate dry season flows are too high to maintain abundant wild salmonid populations (Pess et al. 2002, Smith 2002). A boundary at $60 \%$ forest cover is lower than the more commonly used $65 \%$ value (Booth et al. 2002) because naturally unforested alpine areas in the upper Nooksack basin are extensive. When watershed forest cover declines below $60 \%$, coho salmon abundances are less than half as large as abundances in fully forested watersheds (derived from results in Pess et al. [2002]). For salmon populations already at risk, abundance reductions that large represent risks of declines or extinction equivalent to a boundary.

\section{Current status}

Forest cover varies across the county, primarily because of land use and secondarily because of elevation. In the area west of federal lands, mean forest cover is 55.0\% (Table 3; Pierce 2015). Forest cover in some urbanized and agricultural watersheds is as low as $10 \%$ (Smith 2002). Forest cover on federal lands is greater (Table 3; Mt. Baker Ranger District 1995, 2006), where nonforest cover primarily occurs at high elevations in alpine meadows, snowfields, and glaciers. The area-weighted average forest cover for the Nooksack basin is $60.7 \%$, a value marginally within the boundary. If forest loss continues at recent rates (Table 3), the boundary soon will be exceeded.

Table 3. Forest cover and loss in the Nooksack River basin. The left columns distinguish between forest on federal (U.S. Forest Service and National Park Service) land versus nonfederal public and privately owned land to the west. Columns on the right report forest loss for entire subbasins, including both federal and nonfederal lands. Almost all forest loss occurred on nonfederal lands. Calculated from data in Mt. Baker Ranger District (1995, 2006), Pierce (2015), and Muller (2015).

\begin{tabular}{|c|c|c|c|}
\hline Nooksack River Subbasin & $\begin{array}{l}\% \text { Forest } \\
\text { Cover }^{\dagger}\end{array}$ & $\begin{array}{l}\text { Nooksack River } \\
\text { Subbasin }\end{array}$ & $\begin{array}{c}\% \text { Loss } \\
(2006-2011)\end{array}$ \\
\hline North Fork, federal land & 78.0 & North Fork & 1.1 \\
\hline Middle Fork, federal land & 85.9 & Middle Fork & 1.6 \\
\hline South Fork, federal land & 88.5 & South Fork & 4.2 \\
\hline $\begin{array}{l}\text { Whatcom County, west of } \\
\text { federal land boundary }{ }^{\star}\end{array}$ & 55.0 & $\begin{array}{l}\text { Main-stem } \\
\text { Nooksack }\end{array}$ & 1.5 \\
\hline Total, weighted mean & 60.7 & $\begin{array}{l}\text { Total, weighted } \\
\text { mean }\end{array}$ & 1.1 \\
\hline
\end{tabular}

${ }^{\dagger}$ Determined from 2009 aerial imagery (Mueller 2015, Pierce 2015).

${ }^{\ddagger}$ Includes some land within Whatcom County outside the Nooksack basin.

\section{Riparian forest cover}

Riparian forests support many river system functions, particularly in the Pacific Northwest. A large literature documents these functions, which include moderating impacts of high river flows, maintaining base flows, stabilizing river channels, shaping geomorphology with large woody debris (LWD), improving aquatic habitat quality, providing insects and leaf litter to riverine food webs, supporting wildlife that disperse marinederived nutrients, and maintaining water quality (Naiman et al. 2000, Moore and Palmer 2005, Helfield and Naiman 2006, Violin et al. 2011, Hjältén et al. 2016). Riparian forests maintain water quality through several mechanisms, including moderating water temperature by shading channels, filtering contaminants from surrounding land uses, and reducing sediment erosion and water turbidity (Castelle et al. 1994). Riparian forests often contain wetlands, which reduce flood impacts, contribute water to base flows, filter contaminants, and provide habitat for many fish and wildlife. Restoring riparian forests is a prerequisite for salmon conservation over medium to long timescales (Montgomery et al. 2003, Beechie et al. 2013, DeBano et al. 2016). Functions supported by riparian forests are particularly important in the Nooksack River basin, because of the river's regional importance. Among rivers south of the international border, the Nooksack discharges the fourth largest volume of water into the Salish Sea, and it is second only to the Skagit River in sediment discharge (Czuba et al. 2011). The quantity, quality, and timing of these discharges depend in part on the extent of riparian forest cover (Pess et al. 2002).

Determining the boundary for riparian forest loss is difficult because of confounding influences on riparian functions by several factors, including adjacent land uses and extent of watershed development. Incomplete buffers of riparian forest 
cannot mitigate impacts of extensive urban or agricultural land uses (Walsh et al. 2007, Wahl et al. 2013). It is not known whether continuous forest buffers can mitigate cumulative impacts of land use across a watershed (Wahl et al. 2013), attributable in part to correlations between watershed-scale land-use patterns and riparian buffer condition (Moore and Palmer 2005, Wasson et al. 2010). Forest buffers may alleviate adjacent land-use impacts if they filter runoff (Bernhardt and Palmer 2007), but this function is constrained by development extent at a watershed scale (Walsh et al. 2007). The WRIA salmonid recovery plan set a lower limit for "good" condition at $70 \%$ riparian forest cover within the historical channel migration zone (WRIA 1 Salmon Recovery Board 2005a, b). Because of the importance of buffering intensive agricultural land uses along most of the Nooksack, the $70 \%$ value provides a lower estimate for the riparian forest cover boundary.

Consequences of riparian forest cover falling below $70 \%$ include channel instability, elevated high flows and lower low flows, increased summer water temperature, decreased LWD inputs and loss of associated riparian habitat structure, increased water contamination from urban and agricultural sources, and loss of riparian biota, including declines or extinctions of salmonids. When riparian forest cover declines below $70 \%$, coho salmon abundances are less than $74 \%$ of abundances in fully forested watersheds (derived from results in Pess et al. [2002]).

\section{Current status}

Riparian forest cover falls below $70 \%$ in every Nooksack subbasin, although the North Fork and Middle Fork subbasins approach that boundary (Table 4). Forest cover in the main-stem Nooksack riparian zone is substantially below 70\%, largely because of forest conversion to agricultural uses in the late 19th and early 20th centuries (NWIFC 2016). Although riparian forest loss slowed during the later 20th century, and riparian restoration has been extensive in recent decades, contemporary net loss continues (Table 4; Muller 2015). All of the likely consequences of low riparian forest cover are occurring, although most wild salmonid populations persist at low abundances.

\section{Freshwater use}

Gerten et al. (2013) advocated determining boundaries on water use with a bottom-up approach, based on spatially explicit flows required to maintain river functions. Most river system functions are flow dependent (Poff et al. 1997). Anthropogenic changes to river flows affect these functions in diverse ways (Poff and Zimmerman 2010). Water withdrawals from surface and groundwater sources tend to be greatest when freshwater is least available in western North America. Domestic, commercial, and industrial water uses tend to remain consistent throughout the year, but most water withdrawals are used for irrigation during the dry summer season (Hirst 2015). Water withdrawals during low flows are particularly impactful, causing decreased water quality, decreased dissolved oxygen, increased water temperature, riparian vegetation losses, reduced riverine habitat extent and diversity, losses in aquatic invertebrate abundance and diversity, fish migration barriers, and declines of cold-water fishes (Poff et al. 1997, Van Kirk and Naman 2008). Stream flow, water quality, and water temperature are strongly related in western Washington and elsewhere (Mohseni et al. 1998). High temperatures can limit salmonid distribution, migration, survival, and vulnerability to disease (McCullough 1999, Richter and Kolmes 2005, Farrell et al. 2008, Meyers et al. 2008).
Table 4. Forest cover in the Nooksack River historical channel migration zone. Values are ratios of riparian forest area to total riparian area, expressed as percentages. Riparian forest cover values were determined from 2013 LIDAR (light detection and ranging) data (Northwest Indian Fisheries Commission 2016). Recent (2006-2011) percent losses of riparian forest cover determined for each subbasin are from Muller (2015). Forest loss values aggregate Everson-Forks confluence, main-stem Nooksack, and Nooksack delta reaches into a single subbasin.

\begin{tabular}{lcc}
\hline \hline Nooksack River Reach & $\begin{array}{c}\text { \% Riparian Forest } \\
\text { Cover }\end{array}$ & \% Loss (2006-2011) \\
\hline North Fork & 67 & 0.8 \\
Middle Fork & 66 & 1.5 \\
South Fork & 50 & 1.1 \\
Everson-Forks & 54 & 1.1 \\
confluence & & 1.0 \\
Main-stem Nooksack & 21 & \\
Nooksack delta & 50 & \\
Nooksack basin total & 50 & \\
\hline
\end{tabular}

In western Washington, little precipitation occurs during summer, and many streams and rivers depend on groundwater inflow (Gibbons and Culhane 1994, Water Resources Program, Washington State Department of Ecology 2016). Groundwater inflow to surface waters in the Nooksack basin has not been fully quantified, although it is substantial where measured (Cox et al. 2005, Gendaszek 2014). Cool groundwater inputs partially mitigate impacts of warm summer air temperatures (Snyder et al. 2015). Melting glaciers discharge cold water into the Nooksack's north and middle forks, but in decreasing quantities as glaciers recede (Murphy 2016). Similarly, snowmelt inputs are decreasing in volume and duration as mountain snowpacks shrink and melt earlier (Mantua et al. 2010).

I used a river-specific analogue of the environmental flow requirement (EFR) methods applied in Gerten et al. (2013). A river-specific approach determines the region-specific boundary more accurately and provides stronger legal basis for policy. The Washington State Department of Ecology established minimum in-stream flow regimes for Washington rivers, based largely on fish habitat quality and quantity (Water Resources Program, Washington State Department of Ecology 2009). Minimum flows were established for the Nooksack basin in 1985 (Water Resources Planning and Management Section, Washington State Department of Ecology 1985). These EFRs determine an upper boundary for freshwater use, because additional withdrawals risk disrupting river functions, including potentially irreversible extinctions of unique fish populations. Future reviews may require raising EFRs and reducing withdrawals to address needs of protected salmonids (Beechie et al. 2013) and federal adjudication of tribal water rights.

\section{Current status}

In the three decades since the Washington State Department of Ecology established minimum flows, Nooksack EFRs have never been met throughout an entire year, and flows have fallen below minima on average 142 days $(39 \%)$ of the year (Loranger 2016). Failure to maintain flows above the minimum has been most frequent and severe during summer, when EFR is most important. 
From 1986 to 2017, the main-stem Nooksack fell below EFRs $74 \%$ of summer days (15 July to 15 September; NWIFC 2012, U. S. Geological Survey [USGS] 2017). During the warm and dry summers of 2016 and 2017, the Nooksack fell below minimum flows $100 \%$ of summer days (USGS 2017). Since 2010, the mean summer daily water deficit has been $24 \%$ below minimum flow levels (USGS 2017).

Climatic changes are likely to widen the gap between summer flows and EFRs throughout the century. As winter temperatures warm, upper subbasins are forecast to shift from snow dominated to rain dominated or mixed rain and snow dominated (Mantua et al. 2010). The resultant loss of the hydrograph peak in late spring and early summer is forecasted to reduce median July stream flow by $34 \%, 26 \%, 42 \%$, and $34 \%$ in the North Fork, Middle Fork, South Fork, and main-stem Nooksack River by the year 2025 (Murphy 2016). By the year 2075, forecasted reductions in median July flows are $77 \%, 65 \%, 76 \%$, and $72 \%$, respectively (Murphy 2016).

Chronic failure to meet EFRs reveals overappropriation of water in the Nooksack basin, including uses guaranteed by legal water rights, uses with ambiguous legal justification, and illegal withdrawals. Overappropriation has become more severe, despite closures and EFR designation. Until 2016, the Whatcom County Planning and Development Services Department circumvented subbasin closures by approving rural development applications involving "permit-exempt" wells (Melious 2017). Many wells withdraw groundwater that is hydrologically connected to the Nooksack, consequently reducing in-stream flows. In the three decades since Washington State Department of Ecology established in-stream flows, more than 7000 additional wells have been drilled in subbasins closed seasonally or year-round (NWIFC 2012, 2016). Recently, the Washington Supreme Court (2016) ruled this practice illegal.

\section{Phosphorus flows}

Phosphorus is the limiting nutrient in many freshwater systems (Carpenter 2005). Heavy phosphorus influxes induce freshwater eutrophication by supporting algal growth, leading to blooms in warm weather. In lakes, dead algae sink to the hypolimnion where their decomposition produces anoxic conditions that persist until autumn turnover. These processes increasingly occur in Lake Whatcom, the drinking water source for about half the county's human population (Pickett and Hood 2008). In 1998, the lake was declared an "impaired water body" because of an increasing rate and extended period of hypolimnion oxygen depletion (Pickett and Hood 2008). Oxygen depletion is linked to algal growth and die-off, stimulated by phosphorus influxes into the lake (Matthews et al. 2002). Phosphorus is the limiting nutrient throughout most of the lake during most of the year (Matthews et al. 2002). The majority of anthropogenic phosphorus influxes originate from residential development in the watershed, including storm water, fertilizers, detergents, septic systems, livestock and pet manure, and erosion of disturbed soil (Hood 2016). Additional phosphorus sources include soil erosion from timber harvesting, recreational trails, and stream banks (Hood 2016).

In 2008, the Washington State Department of Ecology established the total maximum daily load (TMDL) for phosphorus influx to the lake consistent with state water quality standards. It determined the TMDL using a hydrodynamic and water quality model (Berger 2017), calibrated with data on water, sediment, and nutrient inputs from 22 subwatersheds and lake water quality measurements (Pickett and Hood 2008). The TMDL, $14.15 \mathrm{~kg} / \mathrm{d}$ $(5164.75 \mathrm{~kg} / \mathrm{yr})$, provides a boundary for phosphorus influx. After subtracting phosphorus from natural sources, this boundary allows for anthropogenic inputs no greater than $6.86 \mathrm{~kg} / \mathrm{d}(2505.7$ $\mathrm{kg} / \mathrm{yr}$; Table 5). Risks associated with exceeding this boundary include increasingly severe algal blooms, reduction in water quality, increased water treatment costs, drinking water contamination with carcinogenic by-products of water treatment, and mortality of many lake biota. The lake hosts native kokanee salmon (Oncorhynchus nerka), and kokanee eggs from a hatchery at the south end of the lake supply breeding programs throughout the northwestern United States (Hood 2016). The kokanee are affected severely by decreases in dissolved oxygen. If boundary exceedance is severe or prolonged, risk would escalate to loss of the lake as a suitable water source because of a shift to a turbid water eutrophic state (Carpenter et al. 1999).

Table 5. Phosphorous influxes $(\mathrm{kg} / \mathrm{yr})$ to Lake Whatcom: total maximum daily load (TMDL) boundary, 2003 values, and projection under full development allowed under 2003 zoning regulations. Values were derived from Pickett and Hood (2008).

\begin{tabular}{lccc}
\hline \hline Source & $\begin{array}{c}\text { TMDL } \\
\text { Boundary }\end{array}$ & 2003 Levels & $\begin{array}{c}\text { Allowed } \\
\text { Development }\end{array}$ \\
\hline Middle Fork & 293.1 & 293.1 & 293.1 \\
Nooksack diversion & & & \\
Groundwater & 2203.4 & 2203.4 & 2203.4 \\
Precipitation & 162.6 & 162.6 & 162.6 \\
Anthropogenic & 2505.7 & 3622.7 & 5845.2 \\
sources & & & \\
Total & 5164.8 & 6281.8 & 8504.3 \\
\hline
\end{tabular}

\section{Current status}

Phosphorus influxes currently exceed the TMDL boundary by $22 \%$ (Table 5). Anthropogenic sources exceed the anthropogenic TMDL limit by $45 \%$, which excludes natural phosphorus sources beyond human control. Despite regulatory action, variable increases in phosphorus and algal concentrations and decreases in dissolved oxygen have occurred throughout the lake (Matthews et al. 2016). Restoring phosphorus influxes to the boundary will require reducing the development footprint to just $13 \%$ of its 2003 value (Hood 2016). This reduction could be achieved by a combination of reforming land-use practices and restoring some developed land to natural conditions. Continuing residential development in the Lake Whatcom watershed threatens to exacerbate the boundary overshoot. Full development in the watershed allowed by 2003 zoning regulations would exceed the TMDL boundary by $65 \%$, or $233 \%$ of the anthropogenic limit (Table 5). Restoring phosphorus influx to the TMDL boundary under full development would require reducing the effective development footprint to $5.4 \%$ of the its physical area (Hood 2016). The magnitude of potential boundary overshoot increased because of zoning changes since 2003, which include upzoning some rural areas in the watershed to urban densities (Whatcom County Planning and Development Services 2015). 


\section{Nitrogen flows}

Human intervention in the nitrogen cycle occurs largely through agricultural activity: generation and distribution of inorganic fertilizers, cultivation of leguminous crops, and distribution and storage of livestock wastes (Foley et al. 2005). Most agricultural production occurs on land, but most environmental impacts of nitrogen occur in freshwater, estuarine, and coastal marine systems. These impacts include degradation in the quality of groundwater and surface water, freshwater and marine eutrophication, resultant biodiversity losses, and human health problems (Hansen et al. 2017). Surface water and groundwater contamination occur when surface application of fertilizers or manure exceeds local plant uptake capacity in combination with irrigation or heavy precipitation. Under these conditions, unused nitrogen in the form of nitrate mobilizes in water that drains into streams or leaches into groundwater. Groundwater contamination is most common and severe in areas with heavy agricultural nitrogen application, well-drained soils, and shallow water tables (Mitchell et al. 2003).

In the focal region, nitrogen contamination is high in both groundwater and surface water. Groundwater nitrate concentrations in the county's largest aquifer are among the highest in Washington State (Morgan 2016), and the nitrogen yield in the Nooksack is the second greatest among all rivers discharging to the Salish Sea (Inkpen and Embrey 1998). I chose groundwater nitrate concentration in the county's largest aquifer as the boundary indicator for nitrogen flows because of greater threshold clarity and data precision than variables associated with surface water. Because groundwater and surface water share the same drivers of nitrogen flow, and groundwater discharge to the Nooksack River is nearly continuous most of the year (Cox et al. 2005), groundwater nitrate concentration also provides a reasonable surrogate for nitrogen flows to surface water. Fecal coliform contamination of surface waters from livestock manure also affects human health and food safety, but nitrate provides a more direct link to nitrogen flows and the planetary boundary process. Groundwater is an essential human resource: it provides drinking water to $60 \%$ of Washington residents (Morgan 2016), including most rural residents in Whatcom County (Carey and Cummings 2012). The Sumas-Blaine aquifer underlies most lowland area in Whatcom County, including most of the lower Nooksack basin. Four factors render it vulnerable to nitrate contamination: intensive agricultural land use, heavy precipitation, a shallow $(<3 \mathrm{~m})$ water table, and well-drained soils (Mitchell et al. 2003). Because of severe human health consequences and the difficulty of restoring contaminated aquifer water quality, the appropriate boundary value is zero samples exceeding the federal drinking water maximum contaminant limit of $10 \mathrm{mg} \mathrm{N} / \mathrm{L}$.

\section{Current status}

Groundwater monitoring of the Sumas-Blaine aquifer involving samples from 515 wells over 30 years concluded that $29 \%$ of sampled wells exceeded the $10 \mathrm{mg}$ N/L limit (Carey and Cummings 2012). Nearly all (97\%) nitrate contamination derived from intensive agriculture, including $66 \%$ from manure and $27 \%$ from inorganic fertilizers (Morgan 2016). Contamination has persisted for decades despite implementation of best management practices (Mitchell et al. 2003). Regulatory agency responses have been ineffective, relying primarily on voluntary measures (Carey et al. 2012) and manure regulations that are inadequate or not enforced (Burnside 2014).

\section{DISCUSSION}

I outline an approach to developing a regional boundaries framework that can be aggregated from individual regions to large river basins and broader scales. The approach applies properties of hydrologic processes that create natural and conceptual links between regions and across scales. Hydrologic processes integrate DPSIR components within regions and across scales, producing entities most sensitive to impacts and mechanisms to bridge scales. System states for each process can be measured across a range of scales from catchments to the planet, although upscaling may require adjusting some variables to address interregional heterogeneity. The framework focuses on processes characterized by spatial heterogeneity that confounds downscaling. Boundaries for processes driven by globally well-mixed stressors, such as climate change, ocean acidification, and stratospheric ozone depletion, can be determined using global downscaling (Gignac and Matthews 2015, Häyhä et al. 2016). Boundaries for the six regionally heterogeneous processes define safe limits on regional state variables, beyond which irreversible regional impacts are likely. One of the six regional processes, freshwater use, could be restored to its boundary rapidly if substantial societal resistance is resolved. The other five regional processes involve drivers with slow dynamics that can be manipulated only gradually. These require societal intervention long before severe impacts become evident (Biggs et al. 2009). For example, phosphorous influx to Lake Whatcom must be reduced to the boundary before algal blooms and resultant oxygen depletion generate positive feedbacks that precipitate irreversible eutrophication (Pickett and Hood 2008). Measures to reduce drivers of phosphorous influx sufficiently will involve expensive and comprehensive changes to infrastructure and vegetative cover (Hood 2016) that require decades to achieve even under ideal implementation.

\section{Interactions among boundaries}

Most regional processes interact in ways that likely reduce the safe limit of one or more boundaries, similar to interactions that reduce planetary-scale boundaries (Rockström et al. 2009a). Delineating causal chains in a DPSIR framework (Fig. 1) reveals that all drivers and regional boundary state variables have causal links to multiple impacts, and all impacts are affected by changes in multiple state variables. These interactions likely reduce the regional safe operating space, mandating greater caution about approaching boundaries than position relative to individual boundaries would suggest. For example, hydrologic effects of land development can reduce river flow and water availability by reducing aquifer recharge and hastening precipitation runoff. These effects shift the freshwater use boundary downward and also may require a more conservative boundary on riparian forest cover. Boundary interactions are particularly important where multiple boundaries have been transgressed, as in the focal region and all other subglobal analyses reviewed previously.

Links between global and regional processes exist in both directions. All regional processes I identified scale up to global levels, as recommended by Steffen et al. (2015). Global climate change also downscales, affecting all regional processes by compounding regional impacts. Other global boundaries exert weak or uncertain impacts on regional processes I identified. 
Table 6. Regional boundaries in driver-pressure-state-impact-response (DPSIR) framework. Regional variables are analogs of planetary boundaries; relevant Earth-system processes are in the left column. Regional boundary variables measure system states, selected using criteria in Table 2. All boundaries have causal links to multiple impacts, with linkages depicted in Figure 1. Values in the far-right column measure regional boundary transgression (\%), with boundaries normalized to $100 \%$. Labels in this column denote regional status relative to the boundary: the high-risk zone exceeds a boundary more than $50 \%(\geq 150 \%$ of boundary value), intermediate risk exceeds the boundary less than $50 \%$, and the safe space lies within the boundary.

\begin{tabular}{|c|c|c|c|c|}
\hline Regional Process & State Variable & Boundary & Current Value & Status \\
\hline Land-system change & $\begin{array}{l}\text { Impervious surface area (total } \\
\text { impervious surface area) }\end{array}$ & $\leq 10 \%$ Basin area & $15.8 \%$ Basin area & $158 \%$ High risk \\
\hline Land-system change & Forest area & $\begin{array}{l}\leq 3 \% \text { Upper subbasin } \\
\geq 60 \% \text { Basin area }\end{array}$ & $\begin{array}{l}3.2 \% \text { Upper subbasin } \\
60.7 \% \text { Basin area }^{\dagger}\end{array}$ & $98 \%$ "Safe" \\
\hline Land-system change & $\begin{array}{l}\text { Riparian forest cover, historical } \\
\text { channel migration zone }\end{array}$ & $\geq 70 \%$ & $50.0 \%$ Basin mean & 167\% High risk \\
\hline & & & $\begin{array}{l}33.2 \% \text { Main stem } \\
60.3 \% \text { Upper subbasins }\end{array}$ & \\
\hline Freshwater use & Dry season in-stream flow & $\begin{array}{l}100 \% \text { Summer } \\
\text { Days } \geq \mathrm{EFR}^{\ddagger}\end{array}$ & $\begin{array}{l}26 \%(\text { Mean } 1986-2017) \\
0 \% \text { in } 2016,2017\end{array}$ & $385 \%$ High risk \\
\hline Phosphorus flow & $P$ influx to water supply & $\leq 14.15 \mathrm{~kg} / \mathrm{d}$ & $17.2 \mathrm{~kg} / \mathrm{d}$ & $122 \%$ Medium risk \\
\hline Nitrogen flow & Groundwater nitrate concentration & $0 \%$ samples $>10 \mathrm{mg} \mathrm{N} / \mathrm{L}$ & $29 \%>10 \mathrm{mg} \mathrm{N} / \mathrm{L}$ & $129 \%$ Medium risk \\
\hline
\end{tabular}

Impacts of global climate change are reducing safe limits on regional processes, which will require further constraints on human uses or effective mitigation measures.

\section{Application to focal region}

Application of the approach to a county and its associated river basin in Washington (USA) revealed that five of the six boundaries have been exceeded, and the county is close to the sixth (Table 6). Exceeding one or more of the boundaries risks irreversible degradation or nonlinear declines in ecosystem functions. These risks include continued declines and extinctions of wild salmon, losses in terrestrial and riparian biodiversity, flooding and erosion compounded by unstable river channels, severe water shortages in dry years, degradation in surface and groundwater quality, freshwater eutrophication, and human health impacts. Risks to salmonids are manifest in federal listing of Chinook salmon and steelhead trout (Oncorhynchus mykiss) as threatened (Northwest Fisheries Science Center 2015). Wild Chinook salmon stocks in the Nooksack basin have declined to less than $1 \%$ of historical abundances (Nooksack Salmon Enhancement Association 2015). Risk of salmon extinction constitutes an existential cultural threat to the indigenous peoples in the region, whose identity is tied strongly to salmon. Analyses conducted for other basins in the Pacific Northwest ecoregion likely would reach similar conclusions, as suggested by NWIFC (2012, 2016) assessments.

The county's status would be more serious without federal land management policies that have restricted human impacts in the upper Nooksack basin. Federal forest protection policies have maintained total forest cover, upper subbasin development, and upper subbasin river flows within their boundaries. The only river reaches with adequate riparian and total forest cover are on federal lands.

This analysis should compel strong responses in policy, planning, and management to avert consequences listed previously. Although there have been several notable efforts to slow or constrain impacts, cumulative effects of responses have been to exceed the boundaries further. The county's comprehensive plan facilitates expanding TIA (Table 2; Whatcom County Planning and Development Services 2015), forest clearing, and development of agricultural land. Further losses in riparian forest are inevitable because of discretionary exceptions to all riparian protections in the county's Critical Areas Ordinance (Whatcom County Planning and Development Services 2017). Freshwater use has exceeded limits required to maintain EFRs since they were established three decades ago, because of failure to implement relevant regulatory and enforcement mechanisms (NWIFC 2016). Reducing phosphorus influxes to Lake Whatcom will require large reductions in the residential development footprint (Hood 2016). Progress has been made in regulating some phosphorus sources, including soil erosion and septic systems. Nevertheless, zoning regulations permit expanding the development footprint (Table 5; Whatcom County Planning and Development Services 2015). State regulations restrict nitrate and manure contamination of groundwater and surface water, but agency enforcement has been lax or absent (e.g., Atkins 2015). Impacts of climate change are likely to require closer boundaries for most state variables (Battin et al. 2007, Mantua et al. 2010, Murphy 2016), and hence even stronger policy responses. To date, policy and planning largely ignore impacts of climate change (Whatcom County Planning and Development Services 2015).

\section{Policy implications}

This regional boundaries framework provides several imperatives for policy and practice in the focal region and generally. Policy processes must alter drivers and pressures in the DPSIR framework (Fig. 1) to produce outcomes that respect environmental boundaries. Policy processes also must be coordinated across socioeconomic sectors to address boundary interactions. In the focal region, drivers that have caused transgression of five regional boundaries must be reduced, then reduced further to mitigate future impacts of climate change. In most cases, policy and enforcement mechanisms to achieve 
necessary reductions exist already, but they have been ignored or implemented in ways that further exceed boundaries. The county comprehensive plan must be reformed to prevent urban growth area expansion, curb further impervious surface expansion, allow greater urban residential density, and discourage further rural development. The county should develop its comprehensive plan using objective population growth forecasts, instead of the inflated forecasts adopted since 2002 (McLaughlin 2016). Riparian forest cover losses could be prevented by closing discretionary loopholes in the county's Critical Areas Ordinance (Whatcom County Planning and Development Services 2017) and by implementing Floodplains by Design projects (Kousky et al. 2013 ) in reaches lacking adequate riparian forest cover. Some riparian forest increases will occur in future decades with maturation of trees planted in restoration programs conducted by nongovernmental organizations and indigenous tribes. The Washington State Department of Ecology must apply its regulatory authority to prevent withdrawals of surface water and groundwater below the minimum flow boundary and to prevent nitrate contamination of groundwater and surface water. Many agencies could apply diverse strategies to increase water-use efficiency (Hirst 2016). Phosphorus inputs to Lake Whatcom must be reduced by reversing expansion of urban zoning in the watershed and by implementing mandatory programs for septic system inspection and repair. Residential development currently allowed in the Lake Whatcom watershed is so extensive that more comprehensive measures will be required to reduce the development footprint to the phosphorus boundary (Hood 2016). In addition to policy reforms, effective compliance enforcement must be implemented (NWIFC 2016).

The Lummi Nation initiated an alternative approach in 2014 (NWIFC 2016). The Lummi water rights settlement initiative includes riparian habitat restoration, in-stream flow requirements, and water quality. The initiative also contains accountability mechanisms to ensure performance. The Lummi approach and its judicial foundation may provide solutions where the policy processes described previously have failed. Comparable approaches have been implemented in other regions (Wallace et al. 2003).

\section{Future research needs}

Mechanisms for scale translation guided development of this regional boundary framework, but translation to broader scales needs to be implemented. Scale translation would expand boundary delineation from individual subbasins to the encompassing large basin. Then frameworks for multiple basins could be integrated to broader scales. This task may involve overcoming some challenges in hydrologic scaling (Gentine et al. 2012) or applying approaches in Gerten et al. (2013). Analyses for other regions may require different boundary processes, such as altered fire regimes (Mori and Johnson 2013) or regional analogues to the unresolved planetary boundaries, chemical pollution and atmospheric aerosol loading (Steffen et al. 2015). A second major need is to expand the framework in socioeconomic and ethical dimensions (Raworth 2012, Häyhä et al. 2016), similar to Dearing et al. (2014) and Cole et al. (2017). The greatest need is for mechanisms to translate boundary information into effective policy and practice. Boundary delineation may identify imperatives for societal responses, but such responses have been lacking in most regions even when limits and consequences of exceeding them are known. Examples in Whatcom County include impervious surface development beyond reversible impacts, water withdrawals below in-stream flow minima, nitrate contamination in groundwater, and expanding phosphorus sources within the water supply watershed. Integrating scientific information into policy is a large topic of growing importance and concern (Groffman et al. 2010, Malokoff 2017). Boundary delineation is not just another factor to consider when negotiating policy. Boundaries define environmental breaking points that must constrain policy outcomes.

Responses to this article can be read online at: http://www.ecologyandsociety.org/issues/responses. php/10171

\section{Acknowledgments:}

Stefan Freelan conducted spatial analysis of forest cover data. Dave Beatty, Jim Davis, Todd Donovan, Wendy Harris, Jim Helfield, Eric Hirst, David Hooper, Rand Jack, Jean Melious, and Robin Matthews generously provided helpful comments and discussion. The editors and three anonymous reviewers provided exceptionally helpful and thoughtful comments on the manuscript.

\section{LITERATURE CITED}

Alberti, M., D. Booth, K. Hill, B. Coburn, C. Avolio, S. Coe, and D. Spirandelli. 2007. The impact of urban patterns on aquatic ecosystems: an empirical analysis in Puget lowland sub-basins. Landscape and Urban Planning 80:345-361. http://dx.doi. org/10.1016/j.landurbplan.2006.08.001

Allan, J. D. 2004. Landscapes and riverscapes: the influence of land use on stream ecosystems. Annual Review of Ecology, Evolution, and Systematics 35:257-284. http://dx.doi.org/10.1146/ annurev.ecolsys.35.120202.110122

Atkins, D. 2015. Fecal matter pollution in public water: the case of Snydar farm. Crosscut. 4 November. Cascade Public Media, Seattle, Washington, USA. [online] URL: http://crosscut. com/2015/11/fecal-matter-pollution-in-drinking-water-the-case-ofsnydar-farm/

Badger, A. M., and P. A. Dirmeyer. 2016. Remote tropical and sub-tropical responses to Amazon deforestation. Climate Dynamics 46:3057-3066. http://dx.doi.org/10.1007/s00382-015-2752-5

Barnosky A. D., E. A. Hadly, J. Bascompte, E. L. Berlow, J. H. Brown, M. Fortelius, W. M. Getz, J. Harte, A. Hastings, P. A. Marquet, N. D. Martinez, A. Mooers, P. Roopnarine, G. Vermeij, J. W. Williams, R. Gillespie, J. Kitzes, C. Marshall, N. Matzke, D. P. Mindell, E. Revilla, and A. B. Smith. 2012. Approaching a state shift in Earth's biosphere. Nature 486:52-58. http://dx.doi. org/10.1038/nature11018

Battin, J., M. W. Wiley, M. H. Ruckelshaus, R. N. Palmer, E. Korb, K. K. Bartz, and H. Imaki. 2007. Projected impacts of climate change on salmon habitat restoration. Proceedings of the National Academy of Sciences of the United States of America 104:6720-6725. http://dx.doi.org/10.1073/pnas.0701685104 
Beechie T., H. Imaki, J. Greene, A. Wade, H. Wu, G. Pess, P. Roni, J. Kimball, J. Stanford, P. Kiffney, and N. Mantua. 2013. Restoring salmon habitat for a changing climate. River Research and Applications 29:939-960. http://dx.doi.org/10.1002/rra.2590

Berger, C. 2017. CE-QUAL-W2 hydrodynamic and water quality model. Water Quality Research Group, Portland State University, Portland, Oregon, USA. [online] URL: http://www.ce.pdx.edu/ $\underline{\mathrm{w} 21}$

Bernhardt, E. S., and M. A. Palmer. 2007. Restoring streams in an urbanizing world. Freshwater Biology 52:738-751. http://dx. doi.org/10.1111/j.1365-2427.2006.01718.x

Biggs, R., S. R. Carpenter, and W. A. Brock. 2009. Turning back from the brink: detecting an impending regime shift in time to avert it. Proceedings of the National Academy of Sciences of the United States of America 106:826-831. http://dx.doi.org/10.1073/ pnas.0811729106

Boettiger, C., and A. Hastings. 2013. Tipping points: from patterns to predictions. Nature 493:157-158. http://dx.doi. org/10.1038/493157a

Booth, D. B., D. Hartley, and R. Jackson. 2002. Forest cover, impervious-surface area, and the mitigation of stormwater impacts. Journal of the American Water Resources Association 38:835-845. http://dx.doi.org/10.1111/j.1752-1688.2002.tb01000. $\underline{\mathrm{X}}$

Booth, D. B, and C. R. Jackson. 1997. Urbanization of aquatic systems: degradation thresholds, stormwater detention, and the limits of mitigation. Journal of the American Water Resources Association 33:1077-1090. http://dx.doi.org/10.1111/j.1752-1688.1997. tb04126.x

Brabec, E., S. Schulte, and P. L. Richards. 2002. Impervious surfaces and water quality: a review of current literature and its implications for watershed planning. Journal of Planning Literature 16:499-514. http://dx.doi.org/10.1177/088541202400903563

Brook, B. W., E. C. Ellis, M. P. Perring, A. W. Mackay, and L. Blomqvist. 2013. Does the terrestrial biosphere have planetary tipping points? Trends in Ecology and Evolution 28:396-401. http:// dx.doi.org/10.1016/j.tree.2013.01.016

Burnside, J. 2014. Nitrates, fecal coliform from dairies linked to tainted shellfish, tap water. KOMO News. Sinclair Broadcast Group Inc., Seattle, Washington, USA. [online] URL: http:// komonews.com/archive/nitrates-fecal-coliform-from-dairies-linkedto-tainted-shellfish-tap-water

Carey, B., and R. Cummings. 2012. Sumas-Blaine Aquifer nitrate contamination summary. Publication No. 12-03-026. Washington Department of Ecology, Olympia, Washington, USA. [online] URL: https://fortress.wa.gov/ecy/publications/summarypages/1203026. $\underline{\text { html }}$

Carey, B., K. Skipper, and K. Weisman. 2012. Focus on groundwater quality in Whatcom County. Publication No. 12-03-005. Washington Department of Ecology, Olympia, Washington, USA. [online] URL: https://fortress.wa.gov/ecy/ publications/documents/1203005.pdf

Carpenter, S. R. 2005. Eutrophication of aquatic ecosystems: bistability and soil phosphorus. Proceedings of the National
Academy of Sciences of the United States of America 102:10002-10005. http://dx.doi.org/10.1073/pnas.0503959102

Carpenter, S. R., W. A. Brock, G. J. A. Hansen, J. F. Hansen, J. M. Hennessy, D. A. Isermann, E. J. Pedersen, K. M. Perales, A. L. Rypel, G. G. Sass, T. D. Tunney, and M. J. Vander Zanden. 2017. Defining a safe operating space for inland recreational fisheries. Fish and Fisheries 18:1150-1160. http://dx.doi. org/10.1111/faf. 12230

Carpenter, S. R., D. Ludwig, and W. A. Brock. 1999. Management of eutrophication for lakes subject to potentially irreversible change. Ecological Applications 9:751-771. http://dx.doi. org/10.1890/1051-0761(1999)009[0751:MOEFLS]2.0.CO:2

Castelle, A. J., A. W. Johnson, and C. Conolly. 1994. Wetland and stream buffer size requirements - a review. Journal of Environmental Quality 23:878-882. http://dx.doi.org/10.2134/ jeq1994.00472425002300050004x

Cederholm, C. J., D. H. Johnson, R. E. Bilby, L. G. Dominguez, A. M. Garrett, W. H. Graeber, E. L. Greda, M. D. Kunze, B. G. Marcot, J. F. Palmisano, R. W. Plotnikoff, W. G. Pearcy, C. A. Simenstad, and P. C. Trotter. 2000. Pacific salmon and wildlife ecological contexts, relationships, and implications for management. Special Edition Technical Report, prepared for D. H. Johnson and T. A. O'Neil (managing directors), WildlifeHabitat Relationships in Oregon and Washington. Washington Department of Fish and Wildlife, Olympia, Washington, USA. [online] URL: http://wdfw.wa.gov/publications/00063/wdfw00063. pdf

Cole, M. J., R. M. Bailey, and M. G. New. 2014. Tracking sustainable development with a national barometer for South Africa using a downscaled "safe and just space" framework. Proceedings of the National Academy of Sciences of the United States of America 111:E4399-E4408. http://dx.doi.org/10.1073/ pnas. 1400985111

Cole, M. J., R. M. Bailey, and M. G. New. 2017. Spatial variability in sustainable development trajectories in South Africa: provincial level safe and just operating spaces. Sustainability Science 12:829-848. http://dx.doi.org/10.1007/s11625-016-0418-9

Cox, S. E., F. W. Simonds, L. Doremus, R. L. Huffman, and R. M. Defawe. 2005. Ground water/surface water interactions and quality of discharging ground water in streams of the lower Nooksack River basin, Whatcom County, Washington. 2005. Scientific Investigations Report 2005-5255. U.S. Geological Survey, Reston, Virginia, USA. [online] URL: https://pubs. usgs. gov/sir/2005/5255/pdf/sir20055255.pdf

Cuo, L., D. P. Lettenmaier, M. Alberti, and J. E. Richey. 2009. Effects of a century of land cover and climate change on the hydrology of the Puget Sound basin. Hydrological Processes 23:907-933. http://dx.doi.org/10.1002/hyp.7228

Czuba, J. A., C. S. Magirl, C. R. Czuba, E. E. Grossman, C. A. Curran, A. S. Gendaszek, and R. S. Dinicola. 2011. Sediment load from major rivers into Puget Sound and its adjacent waters. U.S. Geological Survey Fact Sheet 2011-3083. U.S. Geological Survey, Tacoma, Washington, USA. [online] URL: http://pubs.usgs.gov/ fs/2011/3083/ 
Dao, H., P. Peduzzi, B. Chatenoux, A. De Bono, S. Schwarzer, and D. Friot. 2015. Environmental limits and Swiss footprints based on planetary boundaries. United Nations Environment Programme/Global Resource Information Database-Geneva, Geneva, Switzerland. [online] URL: http://pb.unepgrid.ch/ planetary boundaries_switzerland_report.pdf

Daskalov, G. M., L. Boicenco, A. N. Grishin, L. Lazar, V. Mihneva, V. A. Shlyakhov, and M. Zengin. 2017. Architecture of collapse: regime shift and recovery in an hierarchically structured marine ecosystem. Global Change Biology 23:1486-1498. http:// dx.doi.org/10.1111/gcb.13508

Dearing, J. A., R. Wang, K. Zhang, J. G. Dyke, H. Haberl, M. S. Hossain, P. G. Langdon, T. M. Lenton, K. Raworth, S. Brown, J. Carstensen, M. J. Cole, S. E. Cornell, T. P. Dawson, C. P. Doncaster, F. Eigenbrod, M. Flörke, E. Jeffers, A. W. Mckay, B, Nykvist, and G. M. Poppy. 2014. Safe and just operating spaces for regional social-ecological systems. Global Environmental Change 28:227-238. http://dx.doi.org/10.1016/j.gloenvcha.2014.06.012

DeBano, S. J., D. E. Wooster, J. R. Walker, L. E. McMullen, and D. A. Hornbeck. 2016. Interactive influences of climate change and agriculture on aquatic habitat in a Pacific Northwestern watershed. Ecosphere 7(6):e01357. http://dx.doi.org/10.1002/ $\underline{\text { ecs } 2.1357}$

Farrell, A. P., S. G. Hinch, S. J. Cooke, D. A. Patterson, G. T. Crossin, M. Lapointe, and M. T. Mathes. 2008. Pacific salmon in hot water: applying aerobic scope models and biotelemetry to predict the success of spawning migrations. Physiological and Biochemical Zoology 81:697-708. http://dx.doi.org/10.1086/592057

Feist, B. E., E. R. Buhle, P. Arnold, J. W. Davis, and N. L. Scholz. 2011. Landscape ecotoxicology of coho salmon spawner mortality in urban streams. PLOS ONE 6(8):e23424. http://dx. doi.org/10.1371/journal.pone.0023424

Feist, B. E., E. R. Buhle, D. H. Baldwin, J. A. Spromberg, S. E. Damm, J. W. Davis, and N. L. Scholz. 2017. Roads to ruin: conservation threats to a sentinel species across an urban gradient. Ecological Applications 27:2382-2396. http://dx.doi.org/10.1002/ eap. 1615

Feldman, D. L. 1992. Institutions for managing global climate change: compliance, fairness, and universal participation. Global Environmental Change 2:43-58. http://dx.doi.org/10.1016/0959-3780 (92)90035-6

Foley, J. A., R. DeFries, G. P. Asner, C. Barford, G. Bonan, S. R. Carpenter, F. S. Chapin, M. T. Coe, G. C. Daily, H. K. Gibbs, J. H. Helkowski, T. Holloway, E. A. Howard, C. J. Kucharik, C. Monfreda, J. A. Patz, I. C. Prentice, N. Ramankutty, and P. K. Snyder. 2005. Global consequences of land use. Science 309:570-574. http://dx.doi.org/10.1126/science.1111772

Foster, C. E. 2014. Diminished ambitions? Public international legal authority in the transnational economic era. Journal of International Economic Law 17:355-397. http://dx.doi.org/10.1093/ jiel/jgu017

Gendaszek, A. S. 2014. Hydrogeologic framework and groundwater/surface-water interactions of the South Fork Nooksack River basin, northwestern Washington. Scientific Investigations Report 2014-5221. U.S. Geological Survey, Reston, Virginia, USA. http://dx.doi.org/10.3133/sir20145221
Gentine, P., T. J. Troy, B. R. Lintner, and K. L. Findell. 2012. Scaling in surface hydrology: progress and challenges. Journal of Contemporary Water Research \& Education 147:28-40. http://dx. doi.org/10.1111/j.1936-704X.2012.03105.X

Gerten, D., H. Hoff, J. Rockström, J. Jägermeyr, M. Kummu, and A. V. Pastor. 2013. Towards a revised planetary boundary for consumptive freshwater use: role of environmental flow requirements. Current Opinion in Environmental Sustainability 5:551-558. http://dx.doi.org/10.1016/j.cosust.2013.11.001

Getz, W. M., C. R. Marshall, C. J. Carlson, L. Giuggioli, S. J. Ryan, S. S. Romañach, C. Boettiger, S. D. Chamberlain, L. Larsen, P. D'Odorico, and D. O'Sullivan. 2018. Making ecological models adequate. Ecology Letters 21:153-166. http://dx.doi.org/10.1111/ $\underline{\text { ele. } 12893}$

Gibbons, T. D., and T. Culhane. 1994. Whatcom County hydraulic continuity investigation. Part 2: basin study of Johnson Creek. Water Resources Program Open File Technical Report 93-08. Washington State Department of Ecology, Olympia, Washington, USA. [online] URL: https://fortress.wa.gov/ecy/ publications/documents/9401.pdf

Gignac, R., and H. D. Matthews. 2015. Allocating a $2{ }^{\circ} \mathrm{C}$ cumulative carbon budget to countries. Environmental Research Letters 10:075004. http://dx.doi.org/10.1088/1748-9326/10/7/075004

Giorgi, F., and R. Avissar. 1997. Representation of heterogeneity effects in Earth system modeling: experience from land surface modeling. Reviews of Geophysics 35:413-437. http://dx.doi. org/10.1029/97RG01754

Green A. J., P. Alcorlo, E. T. H. M. Peeters, E. P. Morris, J. L. Espinar, M. A. Bravo-Utrera, J. Bustamante, R. Díaz-Delgado, A. A. Koelmans, R. Mateo, W. M. Mooij, M. RodríguezRodríguez, E. H. van Nes, and M. Scheffer. 2017. Creating a safe operating space for wetlands in a changing climate. Frontiers in Ecology and the Environment 15:99-107. http://dx.doi. org/10.1002/fee.1459

Groffman, P. M., C. Stylinski, M. C. Nisbet, C. M. Duarte, R. Jordan, A. Burgin, M. A. Previtali, and J. Coloso. 2010. Restarting the conversation: challenges at the interface between ecology and society. Frontiers in Ecology and the Environment 8:284-291. http:// dx.doi.org/10.1890/090160

Hansen, B., L. Thorling, J. Schullehner, M. Termansen, and T. Dalgaard. 2017. Groundwater nitrate response to sustainable nitrogen management. Scientific Reports 7:8566. http://dx.doi. org/10.1038/s41598-017-07147-2

Hastings, A., and D. B. Wysham. 2010. Regime shifts in ecological systems can occur with no warning. Ecology Letters 13:464-472. http://dx.doi.org/10.1111/j.1461-0248.2010.01439.x

Häyhä, T., P. L. Lucas, D. P. van Vuuren, S. E. Cornell, and H. Hoff. 2016. From planetary boundaries to national fair shares of the global safe operating space-how can the scales be bridged? Global Environmental Change 40:60-72. http://dx.doi.org/10.1016/ j.gloenvcha.2016.06.008

Helfield, J. M., and R. J. Naiman. 2006. Keystone interactions: salmon and bear in riparian forests of Alaska. Ecosystems 9:167-180. http://dx.doi.org/10.1007/s10021-004-0063-5 
Hirst, E. 2015. Water use in Whatcom County: 2010 data, estimates, assumptions. Whatcom Watch 24(5). [online] URL: http://www.whatcomwatch.org/php/WW open.php?id=1857

Hirst, E. 2016. How to improve Whatcom water-use efficiency? Whatcom Watch 25(12). [online] URL: http://whatcomwatch.org/ index.php/article/how-to-improve-whatcom-water-use-efficiency/

Hjältén, J., C. Nilsson, D. Jørgensen, and D. Bell. 2016. Foreststream links, anthropogenic stressors, and climate change: implications for restoration planning. BioScience 66:646-654. http://dx.doi.org/10.1093/biosci/biw072

Hood, S. 2016. Lake Whatcom watershed total phosphorus and bacteria total maximum daily loads. Volume 2, Water quality improvement report and implementation strategy. Washington State Department of Ecology, Bellingham Field Office, Bellingham, Washington, USA. [online] URL: https://fortress. wa.gov/ecy/publications/documents/1310012.pdf

Hughes, T. P., S Carpenter, J. Rockström, M. Scheffer, and B. Walker. 2013. Multiscale regime shifts and planetary boundaries. Trends in Ecology \& Evolution 28:389-395. http://dx.doi. org/10.1016/j.tree.2013.05.019

Inkpen, E. L., and S. S. Embrey. 1998. Nutrient transport in the major rivers and streams of the Puget Sound basin, Washington. U.S. Geological Survey (USGS) Fact Sheet 009-98. USGS, Reston, Virginia, USA. [online] URL: https://pubs.usgs.gov/ fs/1998/0009/report.pdf

Jones, R., C. Rigg, and L. Lee. 2010. Haida marine planning: First Nations as a partner in marine conservation. Ecology and Society 15(1):12. http://dx.doi.org/10.5751/ES-03225-150112

Jorgensen, J. C., J. M. Honea, M. M. McClure, T. D. Cooney, K. Engie, and D. M. Holzer. 2009. Linking landscape-level change to habitat quality: an evaluation of restoration actions on the freshwater habitat of spring-run Chinook salmon. Freshwater Biology 54:1560-1575. http://dx.doi.org/10.1111/j.1365-2427.2009.02207. $\underline{\mathrm{x}}$

Konrad, C.P., and D. B. Booth. 2005. Hydrologic changes in urban streams and their ecological significance. American Fisheries Society Symposium 47:157-177.

Kousky, C., S. M. Olmstead, M. A. Walls, and M. Macauley. 2013. Strategically placing green infrastructure: cost-effective land conservation in the floodplain. Environmental Science and Technology 47:3563-3570. http://dx.doi.org/10.1021/es303938c

Lichatowich, J. 2013. Salmon, people, and place: a biologist's search for salmon recovery. Oregon State University Press, Corvallis, Oregon, USA.

Limburg, K. E., and R. E. Schmidt. 1990. Patterns of fish spawning in the Hudson River tributaries: response to an urban gradient? Ecology 71:1238-1245. http://dx.doi.org/10.2307/1938260

Lindenmayer, D., C. Messier, and C. Sato. 2016. Avoiding ecosystem collapse in managed forest ecosystems. Frontiers in Ecology and the Environment 14:561-568. http://dx.doi. org/10.1002/fee. 1434

Lohse, K. A., D. A. Newburn, J. J. Opperman, and A. M. Merenlender. 2008. Forecasting relative impacts of land use on anadromous fish habitat to guide conservation planning. Ecological Applications 18:467-482. http://dx.doi.org/10.1890/07-0354.1

Loranger T. 2016. Whatcom County Council Agenda Bill [ruling in Whatcom County v. Western Washington Growth Management Hearings Board]. Washington Department of Ecology, Olympia, Washington, USA. [online] URL: http://www.whatcomcounty. us/DocumentCenter/View/24098

Malokoff, D. 2017. A matter of fact. Science 355:562-563. http:// dx.doi.org/10.1126/science.355.6325.562

Mantua, N., I. Tohver, and A. Hamlet. 2010. Climate change impacts on streamflow extremes and summertime stream temperature and their possible consequences for freshwater salmon habitat in Washington State. Climatic Change 102:187-223. http://dx.doi.org/10.1007/s10584-010-9845-2

Matthews, R., M. Hilles, and G. Pelletier. 2002. Determining trophic state in Lake Whatcom, Washington (USA), a soft water lake exhibiting seasonal nitrogen limitation. Hydrobiologia 468:107-121. http://dx.doi.org/10.1023/A:1015288519122

Matthews, R. A., M. Hilles, J. Vandersypen, R. J. Mitchell, and G. B. Matthews. 2016. Lake Whatcom monitoring project 2014/2015 Report. Lake Whatcom Annual Reports, 24. Western Washington University, Bellingham, Washington, USA. [online] URL: http://cedar.wwu.edu/lakewhat annualreps/24/

McCullough, D. A. 1999. A review and synthesis of effects of alterations to the water temperature regime on freshwater life stages of salmonids, with special reference to Chinook salmon. EPA 910R-99-010. U.S Environmental Protection Agency, Region 10, Seattle, Washington, USA. [online] URL: http://wvvvv.krisweb. com/biblio/gen_usepa_mccullough_1999.pdf

McGuffie, K., A. Henderson-Sellers, H. Zhang, T. B. Durbridge, and A. J. Pitman. 1995. Global sensitivity to tropical deforestation. Global and Planetary Change 10:97-128. http://dx. doi.org/10.1016/0921-8181(94)00022-6

McLaughlin, J. 2016. Whatcom County population growth forecast comparisons. Whatcom County Council, Bellingham, Washington, USA. [online] URL: http://www.whatcomcounty.us/DocumentCenter/ $\underline{\text { View/16187 }}$

Melious, J. O. 2017. A short chronology of county water shortages. Whatcom Watch 26(3). [online] URL: http:// whatcomwatch.org/index.php/article/a-short-chronology-of-countywater-shortages/

Meyers, T., T. Burton, C. Bentz, and N. Starkey. 2008. Common diseases of wild and cultured fishes in Alaska. Alaska Department of Fish and Game, Anchorage, Alaska, USA. [online] URL: http://www.adfg.alaska.gov/static/species/disease/pdfs/fish_disease_book. pdf

Mitchell, R. J., R. S. Babcock, S. Gelinas, L. Nanus, and D. E. Stasney. 2003. Nitrate distributions and source identification in the Abbotsford-Sumas Aquifer, northwestern Washington State. Journal of Environmental Quality 32:789-800. http://dx.doi. org/10.2134/jeq2003.7890

Mohseni, O., H. G. Stefan, and T. R. Erickson. 1998. A nonlinear regression model for weekly stream temperatures. Water Resources Research 34:2685-2692. http://dx.doi.org/10.1029/98WR01877 
Montgomery, D. R., D. B. Booth, and S. Bolton. 2003. Puget Sound rivers and salmon recovery. Pages $1-13$ in $\mathrm{D} . \mathrm{R}$. Montgomery, S. Bolton, D. B. Booth, and L. Wall, editors. Restoration of Puget Sound rivers. University of Washington Press, Seattle, Washington, USA.

Moore, A. A., and M. A. Palmer. 2005. Invertebrate biodiversity in agricultural and urban headwater streams: implications for conservation and management. Ecological Applications 15:1169-1177. http://dx.doi.org/10.1890/04-1484

Morgan, L. 2016. Washington nitrate prioritization project. Publication No. 16-10-011. Washington Department of Ecology, Olympia, Washington, USA. [online] URL: https://fortress.wa. gov/ecy/publications/documents/1610011.pdf

Mori, A. S., and E. A. Johnson. 2013. Assessing possible shifts in wildfire regimes under a changing climate in mountainous landscapes. Forest Ecology and Management 310:875-886. http:// dx.doi.org/10.1016/j.foreco.2013.09.036

Moscrip, A. L., and D. R. Montgomery. 1997. Urbanization, flood frequency, and salmon abundance in Puget lowland streams. Journal of the American Water Resources Association 33:1289-1297. http://dx.doi.org/10.1111/j.1752-1688.1997.tb03553. $\underline{\mathrm{x}}$

Mt. Baker Ranger District. 1995. Watershed analysis: North Fork Nooksack River. Mt. Baker-Snoqualmie National Forest, U.S. Forest Service, Sedro-Woolley, Washington, USA. [online] URL: http://a123.g.akamai.net/7/123/11558/abc123/forestservic.download. akamai.com/11558/www/nepa/102294 FSPLT3 2571801.pdf

Mt. Baker Ranger District. 2006. Middle Fork and South Fork Nooksack Rivers watershed analysis. Mt. Baker-Snoqualmie National Forest, U.S. Forest Service, Sedro-Woolley, Washington, USA. [online] URL: https://www.fs.usda.gov/Internet/ FSE DOCUMENTS/stelprdb5194609.pdf

Muller, M. 2015. Whatcom County: land cover change by subbasin. Washington Department of Fish and Wildlife, Olympia, Washington, USA.

Murphy, R. D. 2016. Modeling the effects of forecasted climate change and glacier recession on late summer streamflow in the upper Nooksack River basin. Thesis. Western Washington University, Geology Department, Bellingham, Washington, USA. [online] URL: https://cedar.wwu.edu/wwuet/461/

Naiman, R. J., R. E. Bilby, and P. A. Bisson. 2000. Riparian ecology and management in the Pacific coastal rain forest. BioScience 50:996-1011. http://dx.doi.org/10.1641/0006-3568 (2000)050[0996:REAMIT]2.0.CO;2

Nooksack Salmon Enhancement Association (NSEA) 2015. NSEA Spawning Grounds Surveys 2014. NSEA, Bellingham, Washington, USA. [online] URL: https://rive.google.com/file/ d/0B6wn76VBcniQWVZ3MFVkRjV3MVE/view

Northwest Fisheries Science Center. 2015. Status review update for Pacific salmon and steelhead listed under the Endangered Species Act: Pacific Northwest. National Oceanic and Atmospheric Administration Fisheries, Seattle, Washington, USA. [online] URL: http://www.westcoast.fisheries.noaa.gov/ publications/gis maps/maps/salmon steelhead/critical habitat/ wcr salmonid ch esa july2016.pdf
Northwest Indian Fisheries Commission (NWIFC). 2012. State of our watersheds report. NWIFC, Olympia, Washington, USA. [online] URL: http://maps.nwifc.org/sow2012/

Northwest Indian Fisheries Commission (NWIFC). 2016. State of our watersheds. NWIFC, Olympia, Washington, USA. [online] URL: http://nwifc.org/publications/state-of-our-watersheds/

Nykvist, B., A. Persson, F. Moberg, L. Persson, S. Cornell, and J. Rockström. 2013. National environmental performance on planetary boundaries: a study for the Swedish Environmental Protection Agency. Report 6576. Swedish Environmental Protection Agency, Stockholm, Sweden. [online] URL: https:// www.naturvardsverket.se/Documents/publikationer6400/978-91-620-6576-8.pdf

O’Neill, R. V., D. L. DeAngelis, J. B. Waide, and T. F. H. Allen. 1986. A hierarchical concept of ecosystems. Princeton University Press, Princeton, New Jersey, USA.

Pace, M. L., S. R. Carpenter, and J. J. Cole. 2015. With and without warning: managing ecosystems in a changing world. Frontiers in Ecology and the Environment 13:460-467. http://dx.doi. org/10.1890/150003

Palmquist, E. C., B. E. Ralston, D. M. Merrit, and P. B. Shafroth. 2018. Landscape-scale processes influence riparian plant composition along a regulated river. Journal of Arid Environments 148:54-64. http://dx.doi.org/10.1016/j.jaridenv.2017.10.001

Perveen, S. 2012. Scale interactions and implications for water resources, hydrology, and climate. Journal of Contemporary Water Research \& Education 147:1-7. http://dx.doi.org/10.1111/ j.1936-704X.2012.00398.X

Pess, G. R, D. R. Montgomery, E. A. Steel, R. E. Bilby, B. E. Feist, and H. M. Greenberg. 2002. Landscape characteristics, land use, and coho salmon (Oncorhynchus kisutch) abundance, Snohomish River, Wash., U.S.A. Canadian Journal of Fisheries and Aquatic Sciences 59:613-623. http://dx.doi.org/10.1139/ $\underline{\mathrm{f02}-035}$

Pickett, P., and S. Hood. 2008. Lake Whatcom watershed total phosphorus and bacteria total maximum daily loads. Volume 1, water quality study findings. Washington State Department of Ecology, Olympia, Washington, USA. [online] URL: https:// fortress.wa.gov/ecy/publications/documents/0803024.pdf

Pierce, K. 2015. High resolution change detection. Washington Department of Fish and Wildlife, Olympia, Washington, USA. [online] URL: http://www.pshrcd.com/

Poff, N. L., J. D. Allan, M. B. Bain, J. R. Karr, K. L. Prestegaard, B. D. Richter, R. E. Sparks, and J. C. Stromberg. 1997. The natural flow regime: a paradigm for river conservation and restoration. BioScience 47:769-784. http://dx.doi.org/10.2307/1313099

Poff, N. L., and J. K. H. Zimmerman 2010. Ecological responses to altered flow regimes: a literature review to inform the science and management of environmental flows. Freshwater Biology 55:194-205. http://dx.doi.org/10.1111/j.1365-2427.2009.02272.x

Public Financial Management Inc. 2015. The proposed Gateway Pacific Terminal and key impact issues for the Whatcom County economy. Report prepared for Communitywise Bellingham. Public Financial Management Inc., Philadelphia, Pennsylvania, 
USA. [online] URL: http://www.whatcomwatch.org/php/ WW_open.php?id=1885

Raworth, K. 2012. A safe and just operating space for humanity: can we live within the doughnut? Oxfam Discussion Papers. Oxfam GB, Oxford, United Kingdom. [online] URL: http://go.nature. com/HrU9hi

Richter, A., and S. A. Kolmes. 2005. Maximum temperature limits for Chinook, coho, and chum salmon, and steelhead trout in the Pacific Northwest. Reviews in Fisheries Science 13:23-49. http:// dx.doi.org/10.1080/10641260590885861

Rockström, J., W. Steffen, K. Noone, Å. Persson, F. S. Chapin III, E. Lambin, T. M. Lenton, M. Scheffer, C. Folke, H. Schellnhuber, B. Nykvist, C. A. De Wit, T. Hughes, S. van der Leeuw, H. Rodhe, S. Sörlin, P. K. Snyder, R. Costanza, U. Svedin, M. Falkenmark, L. Karlberg, R. W. Corell, V. J. Fabry, J. Hansen, B. Walker, D. Liverman, K. Richardson, P. Crutzen, and J. Foley. $2009 a$. Planetary boundaries: exploring the safe operating space for humanity. Ecology and Society 14(2):32. http://dx.doi. org/10.5751/ES-03180-140232

Rockström, J., W. Steffen, K. Noone, A. Persson, F. S. Chapin III, E. F. Lambin, T. M. Lenton, M. Scheffer, C. Folke, H. J. Schellnhuber, B. Nykvist, C. A. de Wit, T. Hughes, S. van der Leeuw, H. Rodhe, S. Sörlin, P. K. Snyder, R. Costanza, U. Svedin, M. Falkenmark, L. Karlberg, R. W. Corell, V. J. Fabry, J. Hansen, B. Walker, D. Liverman, K. Richardson, P. Crutzen, and J. A. Foley. 2009b. A safe operating space for humanity. Nature 461:472-475. http://dx.doi.org/10.1038/461472a

Roni, P., K. Hanson, and T. Beechie. 2008. Global review of the physical and biological effectiveness of stream habitat rehabilitation techniques. North American Journal of Fisheries Management 28:856-890. http://dx.doi.org/10.1577/M06-169.1

Scheffer, M., S. R. Carpenter, T. M. Lenton, J. Bascompte, W. Brock, V. Dakos, J. van de Koppel, I. A. van de Leemput, S. A. Levin, E. H. van Nes, M. Pascual, and J. Vandermeer. 2012. Anticipating critical transitions. Science 338:344-348. http://dx. doi.org/10.1126/science.1225244

Schiff, R., and G. Benoit. 2007. Effects of impervious cover at multiple spatial scales on coastal watershed streams. Journal of the American Water Resources Association 43:712-730. http://dx. doi.org/10.1111/j.1752-1688.2007.00057.x

Smith, C. J. 2002. Salmon and steelhead habitat limiting factors within WRIA 1, the Nooksack basin. Washington State Conservation Commission, Lacey, Washington, USA. [online] URL: http://www.pugetsoundnearshore.org/supporting_documents/ WRIA 1 Limiting Factors Report.pdf

Snyder C. D., N. P. Hitt, and J. A. Young. 2015. Accounting for groundwater in stream fish thermal habitat responses to climate change. Ecological Applications 25:1397-1419. http://dx.doi. org/10.1890/14-1354.1

Steffen, W., K. Richardson, J. Rockström, S. E. Corell, I. Fetzer, E. M. Bennett, R. Biggs, S. R. Carpenter, W. de Vries, C. A. de Wit, C. Folke, D. Gerten, J. Heinke, G. M. Mace, L. M. Persson, V. Ramanathan, B. Reyers, and S. Sörlin. 2015. Planetary boundaries: guiding human development on a changing planet. Science 347:1259855. http://dx.doi.org/10.1126/science.1259855
Stranko, S. A., R. H. Hilderbrand, R. P. Morgan II, M. W. Stanley, A. J. Becker, A. Roseberry-Lincoln, E. S. Perry, and P. T. Jacobson. 2008. Brook trout declines with land cover and temperature changes in Maryland. North American Journal of Fisheries Management 28:1223-1232. http://dx.doi.org/10.1577/M07-032.1

Swift, T. L., and S. J. Hannon. 2010. Critical thresholds associated with habitat loss: a review of the concepts, evidence, and applications. Biological Reviews 85:35-53. http://dx.doi. org/10.1111/j.1469-185X.2009.00093.X

Teah, H. Y., T. Akiyama, R. San Carlos, O. V. Rayo, Y. T. J. Khew, S. Zhao, L. Zheng, and M. Onuki. 2016. Assessment of downscaling planetary boundaries to semi-arid ecosystems with a local perception: a case study in the middle reaches of Heihe River. Sustainability 8:1233. http://dx.doi.org/10.3390/su8121233

U.S. Geological Survey (USGS). 2017. USGS 12213100 Nooksack River at Ferndale, WA. National Water Information System, USGS Water Resources, Reston, Virginia, USA. [online] URL: http://waterdata.usgs.gov/wa/nwis/uv/?site no $=12213100 \&$ PARAmeter $\mathrm{cd}=00060$

Van Kirk, R. W., and S. W. Naman. 2008. Relative effects of climate and water use on base-flow trends in the lower Klamath basin. Journal of the American Water Resources Association 44:1035-1052. http://dx.doi.org/10.1111/j.1752-1688.2008.00212. $\underline{\mathrm{X}}$

Verburg, P. H., J. A. Dearing, J. G. Dyke, S. van der Leeuw, S. Seitzinger, W. Steffen, and J. Syvitski. 2016. Methods and approaches to modelling the Anthropocene. Global Environmental Change 39:328-340. http://dx.doi.org/10.1016/j.gloenvcha.2015.08.007

Violin, C. R., P. Cada, E. B. Sudduth, B. A. Hassett, D. L. Penrose, and E. S. Bernhardt. 2011. Effects of urbanization and urban stream restoration on the physical and biological structure of stream ecosystems. Ecological Applications 21:1932-1949. http:// dx.doi.org/10.1890/10-1551.1

Wahl, C. M., A. Neils, and D. Hooper. 2013. Impacts of land use at the catchment scale constrain the habitat benefits of stream riparian buffers. Freshwater Biology 58:2310-2324. http://dx.doi. org/10.1111/fwb.12211

Wallace, J. S., M. C. Acreman, and C. A. Sullivan. 2003. The sharing of water between society and ecosystems: from conflict to catchment-based co-management. Philosophical Transactions of the Royal Society, B: Biological Sciences 358:2011-2026. http:// dx.doi.org/10.1098/rstb.2003.1383

Walsh, C. J., K. A. Waller, J. Gehling, and R. M. Nally. 2007. Riverine invertebrate assemblages are degraded more by catchment urbanisation than by riparian deforestation. Freshwater Biology 52:574-587. http://dx.doi.org/10.1111/ j.1365-2427.2006.01706.X

Ward, E. J., J. H. Anderson, T. J. Beechie, G. R. Pess, and M. J. Ford. 2015. Increasing hydrologic variability threatens depleted anadromous fish populations. Global Change Biology 21:2500-2509. http://dx.doi.org/10.1111/gcb.12847

Washington State Legislature. 1990. Revised Code of Washington, $R C W$ 36.70A.040. Washington State Legislature, Olympia, Washington, USA. [online] URL: http://apps.leg.wa.gov/RCW/ default.aspx? cite $=36.70 \mathrm{~A} .040$ 
Washington State Office of Financial Management. 2017. April 1, 2017 population of cities, towns and counties used for allocation of selected state revenues state of Washington. Washington State Office of Financial Management, Olympia, Washington, USA. [online] URL: http://www.ofm.wa.gov/pop/april1/ ofm_april1_population_final.pdf

Washington Supreme Court. 2016. Decision No. 91475-3, Hirst et al. v. Whatcom Co. and W.Washington, USA, and Growth Management Hearings Board, 6 Oct. 2016. Washington Supreme Court, Olympia, Washington, USA. [online] URL: http://www. courts.wa.gov/opinions/pdf/914753.pdf

Wasson J.-G., B. Villeneuve, A. Iital, J. Murray-Bligh, M. Dobiasova, S. Bacikova, H. Timm, H. Pella, N. Mengin, and A. Chandesris. 2010. Large-scale relationships between basin and riparian land cover and the ecological status of European rivers. Freshwater Biology 55:1465-1482. http://dx.doi.org/10.1111/ j.1365-2427.2010.02443.x

Water Resource Inventory Area (WRIA) 1 Salmon Recovery Board. 2005a. Water Resource Inventory Area (WRIA) 1 salmonid habitat restoration strategy (version 2.5a). WRIA 1 Salmon Recovery Board, Bellingham, Washington, USA. [online] URL: http://salmonwria1.org/webfm send/28

Water Resource Inventory Area (WRIA) 1 Salmon Recovery Board. 2005b. WRIA I salmonid recovery plan. Bellingham, Washington, USA. [online] URL: http://salmonwria1.org/ webfm_send $/ 23$

Water Resources Planning and Management Section, Washington State Department of Ecology. 1985. Nooksack Water Resource Inventory Area instream resources protection program including administrative rules (Water Resource Inventory Area \#1). Washington State Department of Printing, Olympia, Washington, USA. [online] URL: https://fortress.wa.gov/ecy/ publications/documents/8511001.pdf

Water Resources Program, Washington State Department of Ecology. 2009. Instream flow study methods used in Washington State. Publication No. 09-11-019. Washington State Department of Ecology, Olympia, Washington, USA. [online] URL: https:// fortress.wa.gov/ecy/publications/documents/0911019.pdf

Water Resources Program, Washington State Department of Ecology. 2016. Nooksack Watershed, WRIA 1. Publication No. 11-11-006. Washington State Department of Ecology, Olympia, Washington, USA. [online] URL: https://fortress.wa.gov/ecy/ publications/documents/1111006.pdf

Whatcom County Planning and Development Services. 2015. Final EIS: Whatcom County 2016 comprehensive plan and development regulations update and urban growth areas review. Whatcom County Planning and Development Services, Bellingham, Washington, USA. [online] URL: http://www. whatcomcounty.us/1178/Environmental-Impact-Statement

Whatcom County Planning and Development Services. 2017. Whatcom County code title 16.16: critical areas ordinance. Whatcom County Planning and Development Services, Bellingham, Washington, USA. [online] URL: http://www. codepublishing.com/WA/WhatcomCounty/html/WhatcomCounty16/ $\underline{\text { WhatcomCounty } 1616 . h t m l \# 16.16}$
Zheng, H., L. Yifeng, B. E. Robinson, G. Liu, D. Ma, F. Wang, F. Lu, Z. Ouyang, and G. C. Daily. 2016. Using ecosystem service trade-offs to inform water conservation policies and management practices. Frontiers in Ecology and the Environment 14:527-532. http://dx.doi.org/10.1002/fee.1432

Zovanyi, G. 1998. Growth management for a sustainable future. Praeger, Westport, Connecticut, USA. 